\title{
Experiment-supported modelling of salt marsh establishment
}

Daan W. Poppema ${ }^{\mathrm{a}, \mathrm{b}, *}$, Pim W.J.M. Willemsen ${ }^{\mathrm{a}, \mathrm{b}, \mathrm{c}}$, Mindert B. de Vries $^{\mathrm{b}}$, Zhenchang Zhu ${ }^{\mathrm{c}}$, Bas W. Borsje ${ }^{\mathrm{a}}$ and Suzanne J.M.H. Hulscher ${ }^{\mathrm{a}}$

${ }^{a}$ Water Engineering and Management, University of Twente, P.O. Box 217, 7500 AE Enschede, The

Netherlands

${ }^{b}$ Department of Ecosystems and Sediment Dynamics (ESD), Deltares, Delft, The Netherlands

${ }^{c}$ Department of Estuarine and Delta systems, Royal Netherlands Institute for Sea Research (NIOZ), and Utrecht University, P.O. Box 140, 4400 AC Yerseke, The Netherlands

*Corresponding author, e-mail: $\underline{\text { d.w.poppema@utwente.nl }}$

$10 \quad$ Article information

Version: Preprint

For published article, see Ocean \& Coastal Management, 2019: doi.org/10.1016/j.ocecoaman.2018.10.039

\section{Keywords}

Windows of Opportunity framework, seedling establishment, vegetation dynamics, ecological engineering, design tool

\section{Highlights}

- The survival of Spartina anglica seedlings is sensitive to bed level change.

- Bed level change is included in the revised Windows of Opportunity (WoO) framework to better predict vegetation growth.

- Applying the $\mathrm{WoO}$ framework to a marsh creation project showed the need for wave dampening measures.

- The $\mathrm{WoO}$ framework is a suitable design tool for salt marsh restoration/creation.

\section{Abstract}

Recently, the use of salt marshes in front of hard structures is increasingly proposed as a more sustainable coastal protection measure. Yet, salt marsh restoration and creation is often hampered by the lack of a thorough understanding of initial vegetation establishment. Recent studies highlight the importance of bed level change for salt marsh development. In this study we continue the examination of the impact of bed level change on salt marsh development, focussing on the prediction of salt marsh establishment and the implications for coastal management. First, a test with Spartina anglica seedlings (Cordgrass) in a wave flume showed that long-term (seasonal) bed level change is more important for seedling survival than direct wave impact at the shoot. Therefore, we subsequently incorporated bed level change in the Windows of Opportunity (WoO) framework. Lastly, this revised WoO framework was applied to the design of the Marconi pioneer salt marsh pilot (The Netherlands). Combining the WoO framework with a morphodynamic model (Delft3D) showed its potential for salt marsh design. The framework can be used to determine whether salt marsh establishment is possible, to find out which conditions are limiting establishment and to design engineering measures creating the conditions that facilitate salt marsh establishment. 


\section{Introduction}

40 In the face of global warming, the use of ecosystem-based flood defences like salt marshes has become a hot topic. Salt marshes attenuate waves and stabilize the bed, thereby improving coastal safety (Temmerman et al., 2013; Fagherazzi, 2014; Möller et al., 2014). Furthermore, they provide a habitat and nursery ground for both rare and commercially important species (Vernberg, 1993; Beck et al., 2001), filter the water (Nelson \& Zavaleta, 2012) and function as a carbon sink (Brevik \& Homburg, 2004; Chmura, 2013; Duarte et al., 2013). Because salt marshes trap sediment, they can - within limits - keep up with sea level rise (e.g. Kirwan \& Megonigal, 2013). This is in direct contrast with conventional measures like dikes, which are built at a fixed elevation or even decrease in elevation due to processes like soil subsidence and compaction (Temmerman et al., 2013). Due to the abovementioned ecosystem services that salt marshes provide and their ability to grow with sea level rise,

50 engineering solutions that incorporate the use of salt marshes may be more effective and cost-efficient than traditional engineering solutions that do not so (Turner et al., 2007; Broekx et al., 2011). This potential has resulted in several (partly overlapping) rationales aiming to actively use the aforementioned ecosystem services, such as ecological engineering (Borsje et al., 2011), building with nature (Van Slobbe et al., 2013) or nature-based flood defence (Vuik et al., 2016).

55 It is within this context that scientists, lawmakers, and coastal managers are trying to determine how they can predict, evaluate and use the ecosystem services that salt marshes offer (Spalding et al., 2014; Janssen, 2015; Vuik et al., 2018a). Restoration of historically reclaimed salt marshes occurs widely in both Europe and North America, predominantly with the goal of habitat creation and restoration (Wolters et al., 2005; Roman \& Burdick, 2012) and occasionally also to improve coastal safety (Pethick, 2002). However, the initial marsh establishment forms a complex phase in salt marsh restoration and creation projects. Young seedlings have a lower tolerance to waves and disturbances, but the mudflats where salt marshes establish form a harsher environment than the more sheltered existing marshes where older plants can be found (Corenblit et al., 2011; Bouma et al., 2016; Cao et al., 2018). So indepth knowledge on the establishment of salt marshes is needed to improve the success of salt marsh restoration projects and to facilitate the wider use of salt marshes as a coastal protection measure.

It is essential for the successful establishment of a salt marsh that the necessary physical, biological and chemical conditions are met (Friess et al., 2012; Smith \& Warren, 2012). Primarily, this means that elevation should be suitable and that the hydrodynamic conditions should be calm (Vernberg, 1993; Crooks et al., 2002; Powell et al., 2017). If waves or currents are too strong, the drag force on seedlings can dislodge them directly or erosion can cause the uprooting of seedlings over time. Furthermore, the sediment should contain sufficient organic material (Smith \& Warren, 2012) and the drainage should be sufficient to prevent waterlogging of the soil and to transport nutrients, plant seeds and sediment into the marsh (Crooks et al., 2002; Wolters et al., 2005)..

To determine whether the hydrodynamic conditions allow for salt marsh establishment, the Windows of Opportunity (WoO) framework can be used. This framework was originally developed by Balke et al. (2011) for mangrove seedlings and more recently applied to salt marsh establishment (Attema, 2014; Balke et al., 2014; Hu et al., 2015b). The framework states that seedlings can establish when the local conditions remain below the thresholds of the subsequent windows of opportunity. Seedlings require a short disturbance-free period to grow roots (WoO1), followed by a period with calm hydrodynamic conditions (WoO2) in which the plants can grow stronger. After this, in WoO3, high-energy events should not exceed the uprooting limits of vegetation. Using hindcasting $\mathrm{Hu}$ et al. (2015b) applied this framework to salt marsh establishment and defined the limits of the second window in terms of bed shear stress (BSS). Attema (2014) also implemented the third window to predict long-term saltmarsh development, and defined both windows in terms of bed shear stress. 
85 According to $\mathrm{Hu}$ et al. (2015b), hydrodynamics mainly cause seedling failure through erosion of the sediment: the drag force on seedlings is of lesser importance due to their limited frontal area. In their application of the framework, BSS was used as a proxy for erosion. However, BSS only expresses the conditions at a specific point in time, while sedimentation and erosion add up over time. Slowly continuing erosion can have a dramatic effect over time without strong BSS peaks occurring. This effect

90 is also shown for mature salt marshes by Leonardi et al. (2016), who found that most erosion occurs during moderate events instead of extreme events. Furthermore, BSS does not include the effect of sedimentation compensating for erosion. Despite these arguments, bed level change has - to our knowledge - not yet been used directly to predict salt marsh establishment.

Therefore, this study aims to directly use bed level change for the prediction of salt marsh establishment, in order to determine the physical boundary conditions for salt marsh development. Hereto, we define bed level change as the change in bed elevation. In this paper, we (I) examine how plant age, wave height and bed level change during seedling growth affect the survival of Spartina anglica seedlings (hereafter refered to as Spartina) in a flume experiment; (II) expand the WoO framework to explicitly include the influence of bed level change on seedling establishment and (III) determine the physical conditions needed for artificial salt marsh establishment by combining the WoO framework with a morphodynamic model (Delft3D). As a case study for this morphodynamic model, the Marconi project is used, which aims to create an artificial salt marsh in the north of the Netherlands.

The contents of this paper is as follows. Section 2 describes the set-up of the flume experiment (section 2.1), the changes to the $\mathrm{WoO}$ framework to include the effect of bed level change (section 2.2) and the set-up of a morphological model of the Marconi salt marsh (section 2.3). Section 3 presents the results of the flume experiment and the morphological model. In section 4 we discuss the flume experiment, the WoO framework, the morphological model of Marconi and general implications and guidelines for the followed methods. Section 5 ends with the conclusions of the paper.

\section{Methods}

\subsection{Flume experiment}

A flume experiment was designed to determine the impact of plant age, wave height and slowly occurring bed level change on seedling establishment. Previously, Bouma et al. (2016) and Cao et al. (2018) grew Spartina seedlings (Cordgrass) in a climate room and subsequently tested them in a racetrack flume that used currents to induce BSS. They examined the effect of accretion and erosion

115 during seedling growth on the seedling survival rate and critical disturbance depth (CDD). This CDD is defined as the minimum net erosion (difference between erosion and sedimentation), occurring in a short amount of time, that causes a seedling to topple over (cf. Bouma et al., 2016), with short term referring to a period in which no significant plant growth occurs (i.e. days to a week). The concept of CDD is based on the mortality that toppling over of seedlings is expected to cause in the field (Bouma et al., 2016). Their experiments showed that plants are very sensitive to erosion.

Our experiment builds upon the previous experiments, with the difference that a wave flume was used to examine the effect of waves instead of currents produced in a racetrack flume. This choice is based on the findings of Callaghan et al. (2010), that waves are dominant over currents as a forcing mechanism of tidal flats and salt marshes. The goal of the flume experiment was to determine how the critical disturbance depth of pioneer salt marsh vegetation depends on seedling age, wave conditions, and accretion and erosion during seedling growth. Therefore, Spartina seedlings were grown in a climate room and subsequently tested in a wave flume. The following variables were examined: 
- Final age when testing: 10,20 and 40 days;

- Wave height: 3,6 and $9 \mathrm{~cm}$

- Accretion/erosion treatment depth: $-3 ;-1.5 ; 0 ;+1.5 ;+3$ mm weekly.

These values were based on practical feasibility and the fact that previous research (Bouma et al., 2016; Cao et al., 2018) has shown them to be realistic values for in the field, having a measurable impact on seedlings without leading to high mortality rates. The results were subsequently used in the WoO framework to predict seedling establishment. Table 1 below shows the number of seedlings tested in the experiment.

Table 1: An overview of the successfully tested seedlings, for a total of 116 seedlings. The majority of these seedlings was grown in a separate pot. To obtain more samples, some seedlings were grown with 2 to 3 seedlings per pot. The total treatment depth is calculated as the weekly treatment depth times the number of treatments. Starting treatments after 1

140 week, final ages when testing of 10, 20 and 40 days allow for a total of 1, 2 and 5 erosion/accretion treatments. A treatment depth of plus or minus $1.5 \mathrm{~mm} /$ week is not used for the 10-day seedlings, as the combination of a small treatment depth and single application would have very little effect.

\begin{tabular}{crrrrrr}
\hline $\begin{array}{c}\text { Age } \\
\text { [days] }\end{array}$ & $\begin{array}{c}\text { Weekly treatment } \\
\text { depth [mm] }\end{array}$ & $\begin{array}{c}\text { Total treatment } \\
\text { depth [mm] }\end{array}$ & \multicolumn{4}{c}{ Number of seedlings } \\
\hline $\mathbf{1 0}$ & $-3 \mathrm{~mm}$ & $-3 \mathrm{~mm}$ & 2 & 1 & 2 & 5 \\
& $0 \mathrm{~mm}$ & $0 \mathrm{~mm}$ & 4 & 2 & 4 & 10 \\
& $+3 \mathrm{~mm}$ & $+3 \mathrm{~mm}$ & 2 & 2 & 3 & 7 \\
\hline $\mathbf{2 0}$ & $-3 \mathrm{~mm}$ & $-6 \mathrm{~mm}$ & 2 & 3 & 3 & 8 \\
& $-1.5 \mathrm{~mm}$ & $-3 \mathrm{~mm}$ & 2 & 2 & 2 & 6 \\
& $0 \mathrm{~mm}$ & $0 \mathrm{~mm}$ & 3 & 4 & 5 & 12 \\
& $+1.5 \mathrm{~mm}$ & $+3 \mathrm{~mm}$ & 3 & 1 & 3 & 7 \\
& $+3 \mathrm{~mm}$ & $+6 \mathrm{~mm}$ & 1 & 2 & 2 & 5 \\
\hline $\mathbf{4 0}$ & $-3 \mathrm{~mm}$ & $-15 \mathrm{~mm}$ & 5 & 4 & 4 & 13 \\
& $-1.5 \mathrm{~mm}$ & $-7.5 \mathrm{~mm}$ & 4 & 5 & - & 9 \\
& $0 \mathrm{~mm}$ & $0 \mathrm{~mm}$ & 4 & 4 & 3 & 11 \\
& $+1.5 \mathrm{~mm}$ & $+7.5 \mathrm{~mm}$ & 4 & 3 & 3 & 10 \\
& $+3 \mathrm{~mm}$ & $+15 \mathrm{~mm}$ & 4 & 5 & 4 & 13 \\
\hline
\end{tabular}

\subsubsection{Set-up: growing plants}

145 Spartina seeds were collected at the Paulinapolder (in the Western Scheldt) in November 2015. The seeds were stored at $4{ }^{\circ} \mathrm{C}$. They were germinated at room temperature and subsequently germinated at $30^{\circ} \mathrm{C}$, the latter to increase the germination rate. Germination took place in December 2016 and January 2017.

Seedlings were planted in cylindrical PVC pots of $12 \times 16 \mathrm{~cm}$ (diameter $\mathrm{x}$ height) after germination 150 (following Bouma et al., 2016; Cao et al., 2018). The pots were lined with plastic (polyethylene) bags, punctured with holes to enable drainage without loss of sediment. Seedlings were planted with 1 to 3 seedlings per pot, at a depth of $20 \mathrm{~mm}$ to facilitate comparison with earlier experiments (e.g. Bouma et al., 2016). The seedling age is counted from the moment of planting. A commercially bought loamy sand was used for the experiment, with a median grain size of $175 \mu \mathrm{m}$ and a silt content of 10 percent.

155 This silt content fits the Marconi project (see section 2.3 for a description of the project), where the effect of sediment with a silt content of 5, 20 and 50 percent on salt marsh establishment will be examined. 
The plants were grown in a climate room, with a constant temperature of $18{ }^{\circ} \mathrm{C}$ (equal to Bouma et al., 2016). Tidal mesocosms were used to expose the plants to a semi-diurnal tide. The inundation period was $2 \mathrm{hr}$ per tide, which is a typical value for pioneer salt marshes along the Wadden Sea (Bockelmann et al., 2002; De Groot \& Van Duin, 2013; cf. Cao et al., 2018). The salinity used was 23 ppt. The light had an intensity of $250 \mu \mathrm{mol} \mathrm{m} \mathrm{s}^{-1}$, for $18 \mathrm{hr} \mathrm{day}^{-1}$ (equal to Bouma et al., 2016). During the last two weeks of the experiment, the plants were moved to a greenhouse, where the measurements of critical disturbance depth were conducted, with day and night temperatures of approximately $18{ }^{\circ} \mathrm{C}$ and $12{ }^{\circ} \mathrm{C}$ respectively. The light was the natural light of January, which means it was of a higher intensity but shorter duration than in the climate room.

The plants received weekly (after every 7 days) sedimentation and erosion treatments to mimic naturally occurring bed level change. The treatments had a magnitude of $-3 ;-1.5 ; 0 ;+1.5$ and $+3 \mathrm{~mm} / \mathrm{week}$. Erosion treatments were applied by adding a disk at the bottom of a pot and carefully removing the sediment at the surface. Conversely, sedimentation treatments were applied by removing a previously placed disk at the bottom of the pot and adding sediment at the surface (c.f. Balke et al., 2011; Bouma et al., 2016). Due to the polyethylene bags inside, the sediment could be lifted up and down without affecting the sediment or plants. The sediment treatments were performed weekly, starting one week after planting the seedlings.

\subsubsection{Flume test and measurements}

The CDD of the grown plants was determined in a wave flume at the NIOZ in Yerseke, The Netherlands. The wave flume (see Figure 1) has a length of 5 metres and a water depth of 13 to $30 \mathrm{~cm}$. At one side waves were created by a horizontally moving vertical wave paddle, and at the other side a wave dampening mat decreased wave reflection. The time between excursions of the wave paddle was set to approximately 15 seconds, to allow a single wave to fully attenuate before it was created again. Three types of waves were created, with a crest height of 3,6 and $9 \mathrm{~cm}$. The troughs were respectively about 3, 5.5 and $6 \mathrm{~cm}$ deep, due to depth-limiting of the wave height (Massel, 1996). Seedlings were distributed randomly over the different waves, with approximately the same amount of seedlings per wave type.

\section{Top view}

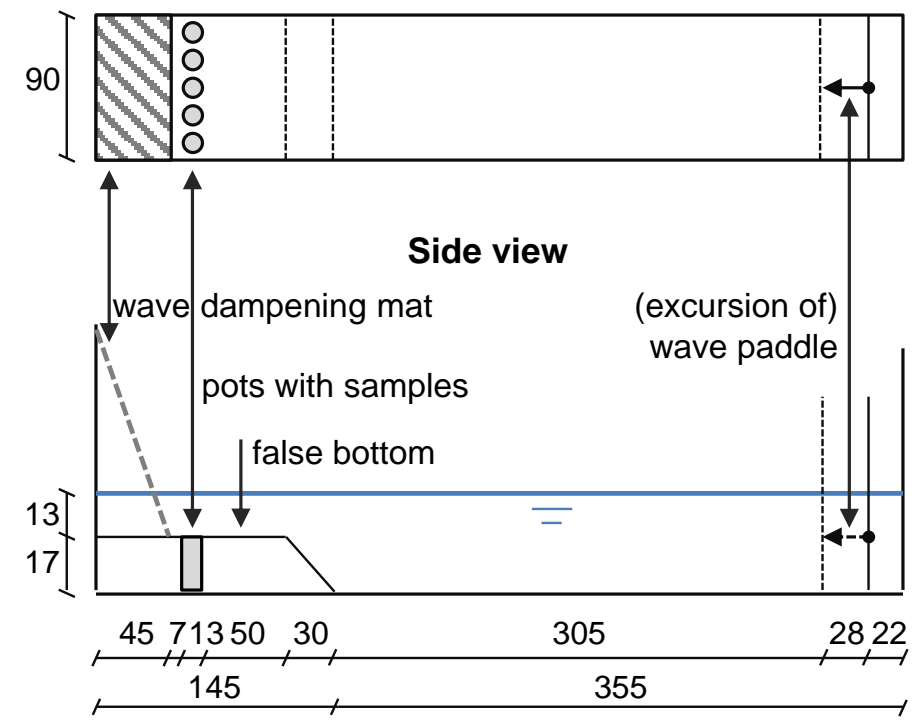

Figure 1: A sketch of the test set-up in the wave flume (with distances indicated in $\mathrm{cm}$ ) 
The plants were exposed to five single waves of identical wave height (either 3,6 or $9 \mathrm{~cm}$ ). If they did not topple over, a disk was inserted at the bottom of the pot and erosion was applied at the top, after which they were tested again. This procedure was repeated until a plant toppled over (c.f. Balke et al., 2011; Bouma et al., 2016). At this point, the total erosion applied to make the seedling topple was recorded as critical disturbance depth (the minimum net erosion, occurring in a short amount of time, that causes a seedling to topple over). The test duration of five waves was chosen to limit the erosion caused by waves. This assured that waves only caused seedling failure by their drag force, and not by erosion. Although this distinction does not exist in the field, it streamlines the analysis. With the followed method, the CDD is by definition equal to the manually applied erosion depth, while otherwise the erosion by waves would make up a part of the CDD.

After a plant toppled over, it was carefully removed from the pot. In case a pot contained multiple plants, the space from which the plant had been removed was refilled with sediment, after which the test continued for the remaining plant(s). As a final step, the mass and length of the root, shoot, aboveground part and below-ground part of the plant were measured. Here, the root length is the length from the original seed to the end of the longest root and the shoot length is the length from the original seed to the top of the plant. The below and above-ground length are the root and shoot length, plus respectively minus the initial burial depth and total treatment depth. A univariate linear regression analysis was used per variable to determine the Pearson correlation coefficient for the effect on the $\mathrm{CDD}$, the average effect (trend line) and the (two-sided) significance level of the effect.

\subsection{Windows of Opportunity framework}

Three windows are defined for the Windows of Opportunity framework (Figure 2). In the first window, seeds require a short disturbance-free period to grow roots. This window is defined as an inundationfree period (Balke et al., 2011; Hu et al., 2015b). In the second window, plants need relatively calm conditions, in order not to be uprooted while growing stronger. In the third window, plants have become mature and able to withstand more energetic conditions. In this section, we redefine the strongest allowable conditions of the second and third windows in terms of bed level change. Hereto, short-term and long-term limits for the (net) erosion and sedimentation rate are used. Here, short-term refers to a period in which no significant plant growth can occur, for which a period of 7 days is used. The longterm limit is defined for the life time of a plant. These short-term and long-term limits are based on the mechanisms through which bed level change can prevent establishment. The framework is quantified for Spartina vegetation, with values based on earlier research and the results of our experiment (see Table 2). 


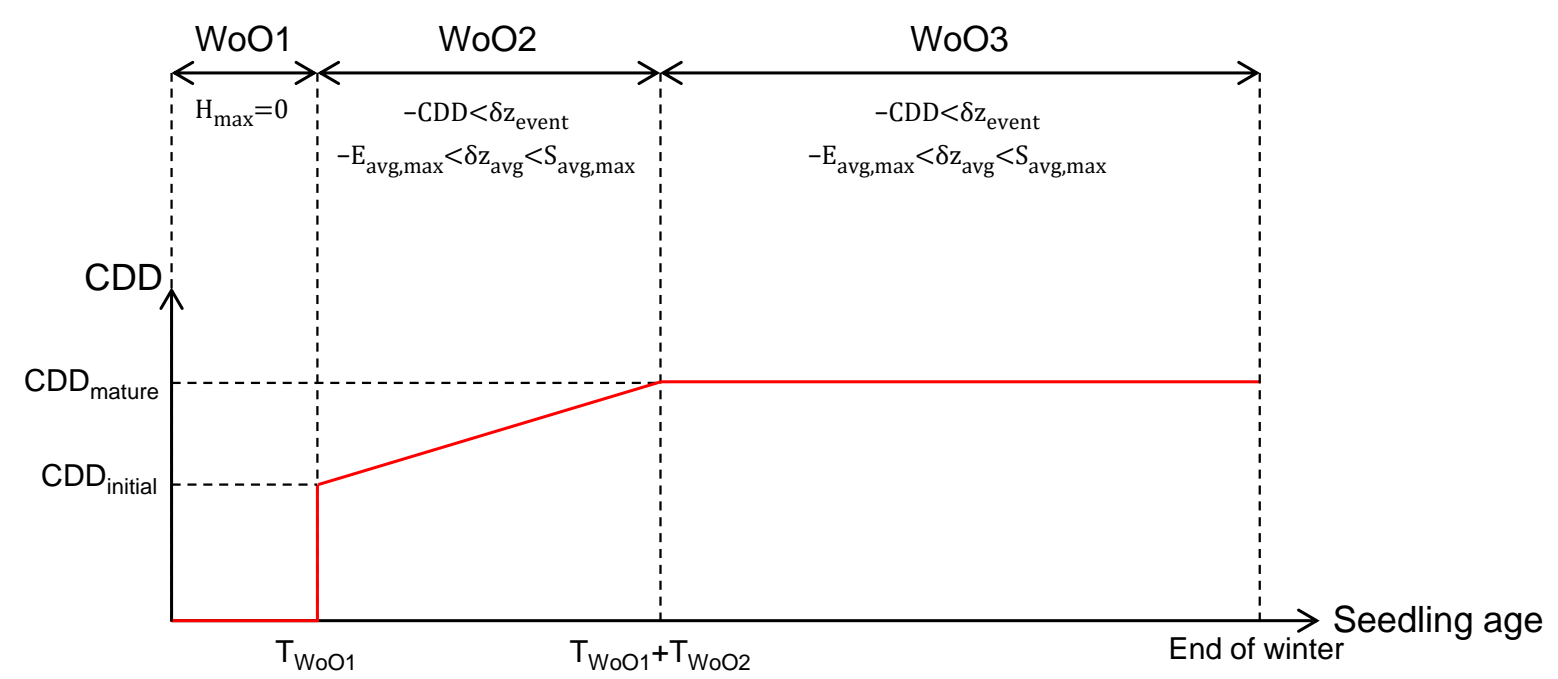

220 Figure 2: Graphical schematization of the Windows of Opportunity framework as used in this study (horizontal axis not on scale). In WoO1, the inundation depth $H_{\max }$ should be zero. In WoO2 and WoO3, the average bed level change during a plants life ( $\left.\delta z_{\text {avg }}\right)$ should be between the long-term erosion limit $E_{\text {avg,max }}$ and long-term sedimentation limit $S_{a v g, m a x .}$ Furthermore, the short-term bed level change ( $\delta z_{\text {event }}$ ) should be less than the critical disturbance depth (CDD). This CDD increases as seedlings grow in WoO2, and becomes constant in WoO3, as shown in the graph. The duration of WoO1 and 225 WO2 are indicated by TWo01 and TWoo2. For the calculation of the CDD, see eq. 3 and eq. 4. For the meaning, value and source of parameters, see also Table 2.

The long-term bed level change limits are based on the growth rate of plants. If the average long-term sedimentation rate exceeds the growth rate of the shoots, plants will be buried and thereby fail. Conversely, if the long-term erosion rate exceeds the growth rate of the roots, the roots will be uncovered. Consequently, they cannot absorb nutrients or anchor the plant, resulting in failure. Given that the growth capacity of a plant is expected to be age-independent, these limits can be defined as constant maxima for the average sedimentation and erosion rate during a plant's life ( $\mathrm{S}_{\text {avg,max }}$ and $\left.\mathrm{E}_{\text {avg,max }}\right)$. This is expressed in eq. 1 , with $\delta z_{\text {avg }}$ being the average net bed level change during a plant's life.

$$
-E_{\text {avg, } \max }<\delta z_{\text {avg }}<S_{\text {avg,max }}
$$

235 The short-term erosion limit checks whether a short-term event can uncover so much of the roots that plants fail. The difference with the long-term limits is that plant growth is insignificant on the timescale of a storm event, and therefore not taken into account. For this limit, the bed level change that occurs in a period $\mathrm{T}_{\mathrm{CDD}}$ is calculated ( $\left.\delta \mathrm{z}_{\text {event }}\right)$. This bed level change should remain below the short-term erosion limit, called critical disturbance depth or CDD (Eq. 2). The CDD depends on the initial burial depth, 240 the seedling age, and the net bed level change during a plant's life, $\delta z_{\text {life. }}$ This is expressed by equation 3 and 4 for $\mathrm{WoO} 2$ and $\mathrm{WoO} 3$ respectively.

The initial burial depth affects the CDD because it determines how much sediment can be eroded before the seed and roots of an undisturbed seedling are uncovered. The seedling age $(t)$ partly determines the root length and thereby the CDD. This is also shown by previous experiments (Bouma et al., 2016), who found that the CDD of Spartina seedlings increases significantly with age. The bed level change during a plants life $\left(\delta z_{\text {life }}\right)$ affects the CDD both directly and indirectly. The direct effect is that sedimentation increases the amount of erosion that can occur before the seedling is uprooted. The indirect effect is that over time bed level change affects the plant growth. Plants can e.g. compensate for erosion by growing longer roots (Cao et al., 2018) and erosion-bared roots can limit nutrient intake and thereby limit plant growth. This effect is expressed by the sensitivity $(\alpha)$ to bed level change. 


$$
\begin{array}{cc}
-C D D<\delta z_{\text {event }} & \text { Eq } 2 \\
C D D_{\text {WoO2 }}=C D D_{\text {initial }}+\frac{t-T_{\text {WoO1 } 1}}{T_{W o O 2}} \cdot\left(C D D_{\text {mature }}-C D D_{\text {initial }}\right)+\alpha \cdot \delta z_{\text {life }} & E q 3 \\
C D D_{\text {WoO3 }}=C D D_{\text {mature }}+\alpha \cdot \delta z_{\text {life }} & E q 4
\end{array}
$$

The end of window 2 indicates the moment that a plant has reached maturity and that the CDD stops increasing. If this window is not finished before the end of the growing season, the plant is probably too weak to survive the winter. Therefore, window 2 fails (by definition). Window 3 starts directly after window 2 and lasts until the end of the winter. If a plant survives all three windows, the establishment is successful.

The value for $\mathrm{T}_{\mathrm{WoO}}$ (Table 2) is based on the results that Hu et al. (2015b) found when hindcasting salt marsh establishment in the Western Scheldt. $\mathrm{T}_{\mathrm{WoO} 2}$ is based on the fact that Bouma et al. (2016) found that the CDD increases at least until an age of 80 days. The limits for the average sedimentation and erosion are based on the mortality that occurred when these values were exceeded in the experiments of Cao et al. (2018). $\mathrm{T}_{\mathrm{CDD}}$, the period over which the short-term erosion is calculated, is chosen such that longer storm events are captured in the period, while the amount of plant growth remains limited. The values for $\mathrm{CDD}_{\text {initial }}, \mathrm{CDD}_{\text {mature, }}$ and $\alpha$ are based on the experiment. The values found for these parameters are explained in section 3.2.

Table 2: The parameter values of Spartina that were used for the WoO framework. The first four values are based on

literature, the last three are based on the experiment (Section 3.1).

\begin{tabular}{llll}
\hline Parameter & Meaning & Value & Source \\
\hline $\mathrm{T}_{\mathrm{WoO} 1}$ & Duration of window 1 & 2.5 days & Hu et al. (2015b) \\
$\mathrm{H}_{\max }$ & Maximum water depth & $0 \mathrm{~m}$ & Hu et al. (2015b) \\
$\mathrm{T}_{\mathrm{WoO} 2}$ & Duration of window 2 & 80 days & Bouma et al. (2016) \\
$\mathrm{E}_{\text {avg,max }}$ & Limit for the average long-term erosion & $5 \mathrm{~mm} / \mathrm{week}$ & Cao et al. (2018) \\
$\mathrm{S}_{\text {avg,max }}$ & Limit for the average long-term & $15 \mathrm{~mm} / \mathrm{week}$ & Cao et al. (2018) \\
& sedimentation & & \\
$\mathrm{T}_{\mathrm{CDD}}$ & Period over which the short-term erosion & 7 days & \\
& is calculated. & & \\
$\mathrm{CDD}_{\text {initial }}$ & CDD at start of window 2 & $16 \mathrm{~mm}$ & Experiment \\
$\mathrm{CDD}_{\text {mature }}$ & CDD of mature vegetation & $23 \mathrm{~mm}$ & Experiment \\
$\alpha$ & Sensitivity to the total bed level change & 1.05 & Experiment \\
& during a plant's life & & \\
\hline
\end{tabular}

\subsection{Morphodynamic model}

As a case study, a morphodynamic model of a salt marsh was set up to model salt marsh establishment and to test how the $\mathrm{WoO}$ framework can be used in modelling studies. The model was set up for the Marconi pioneer salt marsh pilot (see Dankers et al., 2013), located in the Ems and next to the city of Delfzijl, the Netherlands (Figure 3a,b). This salt marsh is being created as part of the Marconi project, which aims to increase the coastal safety and spatial quality of Delfzijl. Simultaneously, the Marconi project aims to obtain generally applicable knowledge about salt marsh creation by experimenting with different measures and designs (e.g. wave breaking measures, the sediment type, and planting or not planting vegetation). The model served a dual purpose. Scientifically, it served as a test for the implementation of the $\mathrm{WoO}$ framework in modelling studies. And practically, it served to predict if and at which elevation salt marsh establishment at Marconi would be possible. 


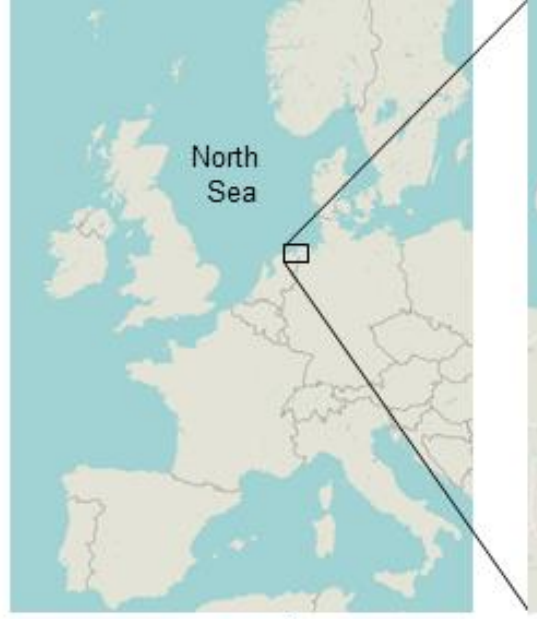

a)

\section{Legend}

--. Water level boundary

--. Velocity boundary

- Wave boundary

Coast

$\leftrightarrow$ Flow direction

$\square$ Area of interest

c)

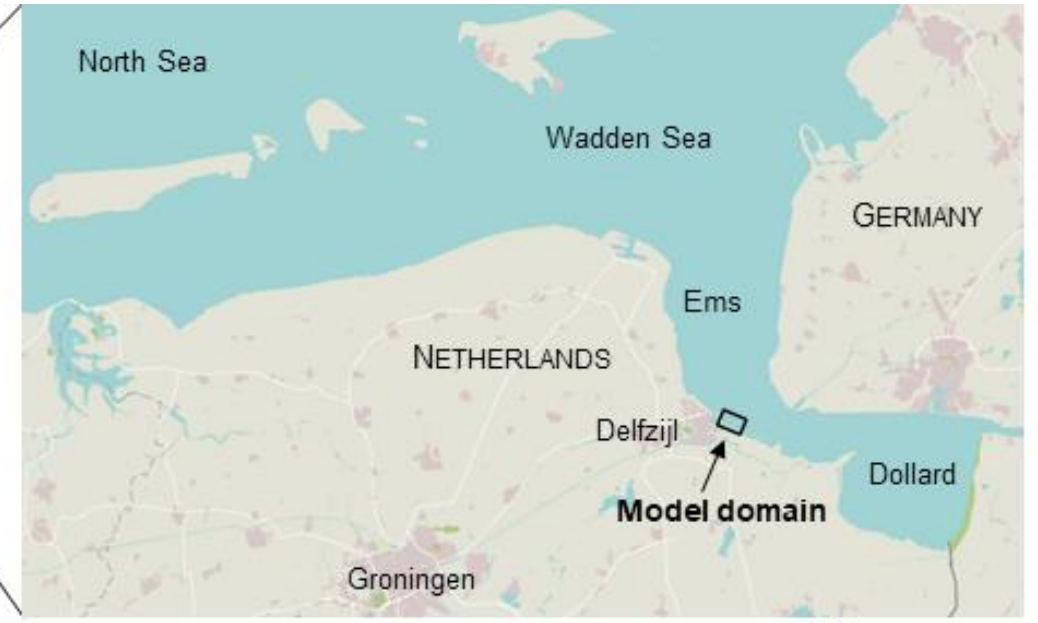

b)

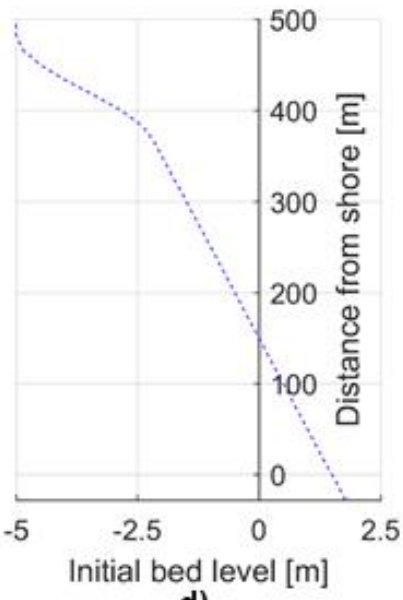

d)

Figure 3: (a) The location of the Marconi project within Europe. (b) A map of Delfzijl and its surroundings. The black box indicates the model domain. (c) A sketch of the model grid (600x535 m), boundary definition, and area of interest. (d) The initial bed level of the model in cross-shore direction (the initial profile is uniform in alongshore direction).

Similar to many previous modelling studies for salt marshes (e.g. Marciano et al., 2005; Temmerman et al., 2005; Schwarz et al., 2014; Best et al., 2018), this model was developed with Delft3D. Delft3D describes the hydrodynamics based on a finite-difference solution of the unsteady shallow-water equations. It applies the horizontal momentum equations, the hydrostatic pressure relation, the continuity equation, the advection-diffusion equation and a turbulence closure model (Lesser et al., 2004). Wave propagation, refraction, dissipation and breaking were calculated with the Delft3D Wave module, which uses a third-generation SWAN model (see Booij et al., 1999). The model was run in a depth-averaged 2DH mode. This significantly decreases computational times and is suitable to obtain a first insight into the morphodynamics of salt marshes, intertidal flats and mangroves (Van Leeuwen et al., 2010; Schwarz et al., 2014; Horstman et al., 2015). The parameter values used in the model are given in Table 3 and further explained in the following paragraphs. 


\begin{tabular}{|c|c|c|c|}
\hline Parameter & Value & Meaning & Source/remarks \\
\hline \multicolumn{4}{|c|}{ Grid and bathymetry } \\
\hline $\mathrm{M}$ & 20 cells & \# cells in $\mathrm{x}$-direction & \\
\hline $\mathrm{N}$ & 40 cells & \# cells in y-direction & \\
\hline$\Delta \mathrm{x}$ & 25 to $50 \mathrm{~m}$ & Grid resolution in $\mathrm{x}$-direction & \\
\hline$\Delta \mathrm{y}$ & 7 to $25 \mathrm{~m}$ & Grid resolution in y-direction & \\
\hline$\Delta \mathrm{t}$ & $8 \mathrm{~s}$ & Time step of model & \\
\hline $\mathrm{Z}_{\min }$ & $-5 \mathrm{~m}$ & Minimum elevation bed & \\
\hline $\mathrm{Z}_{\max }$ & $1.85 \mathrm{~m}$ & Maximum elevation bed & \\
\hline $\mathrm{i}$ & $1: 100$ & (Initial) slope of bed & Applies until $\mathrm{y}=350 \mathrm{~m}$ \\
\hline \multicolumn{4}{|c|}{ Roughness and viscosity } \\
\hline $\mathrm{m}$ & $0.018 \mathrm{~s} / \mathrm{m}^{1 / 3}$ & Manning coefficient & Van Maren et al. (2014) \\
\hline$v$ & $10 \mathrm{~m}^{2} / \mathrm{s}$ & Horizontal eddy viscosity & Willemsen et al. (2016) \\
\hline $\mathrm{K}$ & $10 \mathrm{~m}^{2} / \mathrm{s}$ & Horizontal eddy diffusivity & Willemsen et al. (2016) \\
\hline \multicolumn{4}{|l|}{ Tide } \\
\hline $\mathrm{A}_{1}$ & $1.5 \mathrm{~m}$ & Average amplitude semi-diurnal tide & Rijkswaterstaat (2013) \\
\hline $\mathrm{A}_{2}$ & $21 \mathrm{~cm}$ & Amplitude spring-neap cycle & Rijkswaterstaat (2013) \\
\hline $\mathrm{T}_{1}$ & $12 \mathrm{~h}$ & Duration semi-diurnal tide & \\
\hline $\mathrm{T}_{2}$ & $30 \mathrm{~d}$ & Duration spring-neap cycle & \\
\hline $\mathrm{v}_{\max }$ & $0.7 \mathrm{~m} / \mathrm{s}$ & Maximum flow velocity at channel & Van Maren et al. (2014) \\
\hline \multicolumn{4}{|c|}{ Sediment dynamics } \\
\hline$\rho_{\text {sed }}$ & $2650 \mathrm{~kg} / \mathrm{m}^{3}$ & Specific density sediment & \\
\hline$\rho_{\text {bed }}$ & $500 \mathrm{~kg} / \mathrm{m}^{3}$ & Dry bed density & Van Rijn (1993) \\
\hline $\mathrm{W}_{\mathrm{s}}$ & $0.5 \mathrm{~mm} / \mathrm{s}$ & Settling velocity & Borsje et al. (2008) \\
\hline$\tau_{\mathrm{cr}, \mathrm{e}}$ & $0.5 \mathrm{~N} / \mathrm{m}^{2}$ & Critical bed shear stress erosion & Van Maren et al. (2015b) \\
\hline$\tau_{\mathrm{cr}, \mathrm{s}}$ & $1000 \mathrm{~N} / \mathrm{m}^{2}$ & Critical bed shear stress & Winterwerp and Van \\
\hline & & sedimentation & Kesteren (2004) \\
\hline M & $0.1 \mathrm{mg} / \mathrm{m}^{2} / \mathrm{s}$ & Erosion parameter & Borsje et al. (2008) \\
\hline $\mathrm{C}$ & $100 \mathrm{mg} / \mathrm{L}$ & Sediment concentration at boundary & Van Maren et al. (2015a) \\
\hline
\end{tabular}

\subsubsection{Domain and time frame}

The model domain (Figure 3c) consisted of a rectangular grid of 20 by 40 cells. The resolution in crossshore direction ranged from 7 metres at the coast to 25 metres at the seaward boundary. (Seawards is used here - and throughout this article - as the opposite of landward, even if the Ems is strictly speaking no open sea.) The resolution in alongshore direction was 25 metres in the area of interest (i.e. the area in which vegetation establishment is being modelled). The time step of the model is 8 seconds. The eastern and western boundaries were open, because the predominant currents in the Ems are in alongshore direction. Waves were defined along all non-coastal boundaries.

The bed level ranged from +1.85 to -5 metres (Figure $3 \mathrm{~d}$ ), based on the maximum planned elevation of the salt marsh $(+1.5 \mathrm{~m})$ and a margin to prevent boundary effects. The slope of the bed was 1 percent in seaward direction, based on the design slope of the Marconi pioneer salt marsh. The slope gradually contacts with a channel at -5 metres. In the alongshore direction, the (initial) bed level was uniform. For the roughness a uniform manning coefficient of $0.018\left(\mathrm{~s} / \mathrm{m}^{1 / 3}\right)$ was used, based on earlier modelling 
work of Van Maren et al. (2014) for the Ems and Dollard. The horizontal eddy viscosity and diffusivity were $10 \mathrm{~m}^{2} / \mathrm{s}$ : this is typical for the grid cell size (Deltares, 2016) and similar to what Willemsen et al.

310 (2016) used for a depth-averaged model study with a comparable grid size on sediment transport within a mangrove system.

The modelled period is 1.5 years, of which the first half a year was used as a morphological spin-up time and the last year to test vegetation establishment. During the spin-up time, winter conditions were applied, because most bed level change occurs in this period. The period hereafter started with summer conditions to test establishment, followed by winter conditions to test whether vegetation is able to survive the winter storms.

\subsubsection{Hydrodynamic boundary conditions}

The tidal dynamics of the Ems were represented with two tidal components. The semi-diurnal tide has an average amplitude of $1.5 \mathrm{~m}$ and a period of 12 hours, the spring-neap variation has a period of 30 days and an amplitude of $21 \mathrm{~cm}$ (Rijkswaterstaat, 2013). There is a quarter period phase lag between the water level and flow velocity (Van Maren et al., 2014). The maximum (depth-averaged) flow velocity at the channel was set at $0.7 \mathrm{~m} / \mathrm{s}$ : according to the model of Van Maren et al. (2014) this is a typical value at the Marconi location.

The wave conditions (Figure 4) were defined uniformly along the boundaries. They were defined as a time series, based on the local wave conditions in the year 2012 as modelled by Van Maren et al. (2014). Model runs with decreased wave heights were used to examine the potential effect of wave dampening measures on the morphology and vegetation establishment. Hereto the wave height at the boundaries was decreased with 25 and 50 percent.
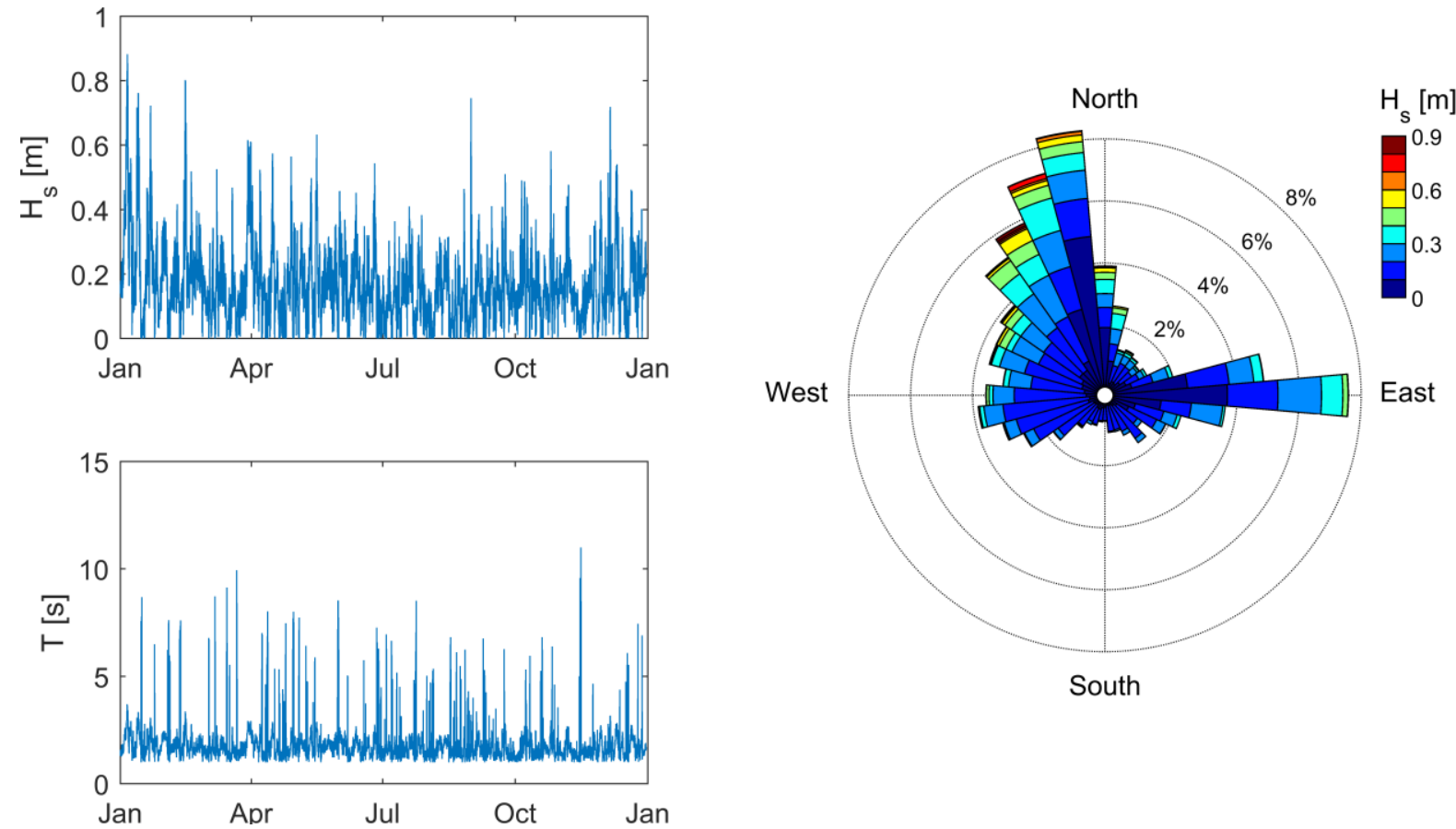

330 Figure 4: A plot of the significant wave height, wave period and direction (origin) of the waves at the boundaries 


\subsubsection{Sediment dynamics}

A uniformly defined homogeneous cohesive sediment (mud) was used, based on the high mud content of the study site and the Ems in general (De Groot \& Van Duin, 2013; Taal et al., 2015). Erosion and sedimentation were calculated by the Partheniades-Krone formulation (Partheniades, 1965), while sediment transport was calculated using the depth-averaged 2D advection-diffusion equation (Deltares, 2016).

The default values of Delft3D were used for the specific density and dry bed density: 2650 and 500 $\mathrm{kg} / \mathrm{m}^{3}$. For the settling velocity a constant value of $0.5 \mathrm{~mm} / \mathrm{s}$ was used, based on the value that Borsje et al. (2008) used for the Dutch Wadden Sea. The critical bed shear stress for erosion was $0.5 \mathrm{~N} / \mathrm{m}^{2}$, based on earlier models of the Ems (Van Maren et al., 2015b). The critical bed shear stress for sedimentation was $1 \mathrm{kN} / \mathrm{m}^{2}$, high enough to comply with the findings of Winterwerp and Van Kesteren (2004) that a critical bed shear stress for sedimentation does not exist. The erosion parameter was set to $0.1 \mathrm{mg} / \mathrm{m}^{2} / \mathrm{s}$, which is the default value of Delft3D and equal to the settings of Borsje et al. (2008).

345 The initial sediment layer was 5 metres thick in the majority of the domain. In the channel (from $y=350 \mathrm{~m}$ onwards, see Figure 3), which in reality likely consists of a coarser and less erodible sediment, the thickness was zero to prevent unrealistic erosion. Between $y=300$ and $y=350$, the sediment thickness decreased linearly. The sediment concentration at the boundary was $100 \mathrm{mg} / \mathrm{L}$, based on local longterm measurements and model studies (Van Maren et al., 2015a). Furthermore, the bed level at the

350 boundaries was set to be constant. Physically, this reflects that the larger system (i.e. the Ems-Dollars) remains constant on the modelled time scale (1 year). Numerically, it improves the model stability.

\subsubsection{Vegetation modelling}

The WoO framework was implemented in Matlab and the output of Delft3D was used to determine if the conditions for establishment were met. This is a one-way coupling, so in this study vegetation has no impact on the hydro- or morphodynamics. The three-hourly output of Delf3D was used. This assures that the tidal maxima and minima are captured exactly (the tidal period being exactly 12 hours). Establishment is only predicted within the area of interest (see Figure 3c). This area is located between the highest planned elevation of the salt marsh $(+1.5 \mathrm{~m})$ and mean sea level $(0 \mathrm{~m})$. In east-west direction, it is limited to the centre of the domain to prevent boundary effects.

\section{Results}

\subsection{Flume experiment}

The flume experiment showed that among the examined variables the total treatment depth (Figure 5a) has the strongest effect on the critical disturbance depth (CDD) of Spartina seedlings. The CDD increased significantly $(\mathrm{p}<0.01)$ with treatment depth and the correlation is strong $\left(\mathrm{R}^{2}=0.81\right)$. Generally, seedlings failed before the burial depth was reached. Furthermore, the plants were very sensitive to accretion and erosion treatments: the slope of the trend line is more than 1, indicating that on average the CDD decreased (increased) more than the applied erosion (accretion) depth.

To prevent the effect of treatments from overshadowing the effect that other variables had on the CDD, the effect of treatments - i.e. the linear trend that was found - was removed from the data. The remaining

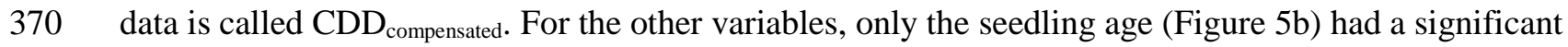
effect on $\mathrm{CDD}_{\text {compensated }}(\mathrm{p}<0.05)$. The positive trend shows that plants generally became stronger with age (i.e. they could withstand more erosion and the CDD increased). However, the correlation is very weak $\left(\mathrm{R}^{2}=0.06\right)$. Root length (Figure $5 \mathrm{c}$ ) and wave height (Figure 5d) showed no significant effect on $\mathrm{CDD}_{\text {compensated }}(\mathrm{p}>0.05)$. Despite the insignificant results, the trends (Figure $5 \mathrm{c} \& 5 \mathrm{~d}$ ) suggest that 
$375 \mathrm{CDD}_{\text {compensated }}$ increased with root length and decreased with wave height. If so, the effect of root length could be caused by a higher resistance to uprooting. The effect of wave height could be caused by the positive effect of wave height on bed shear stress and thereby on the drag force exerted on seedlings.

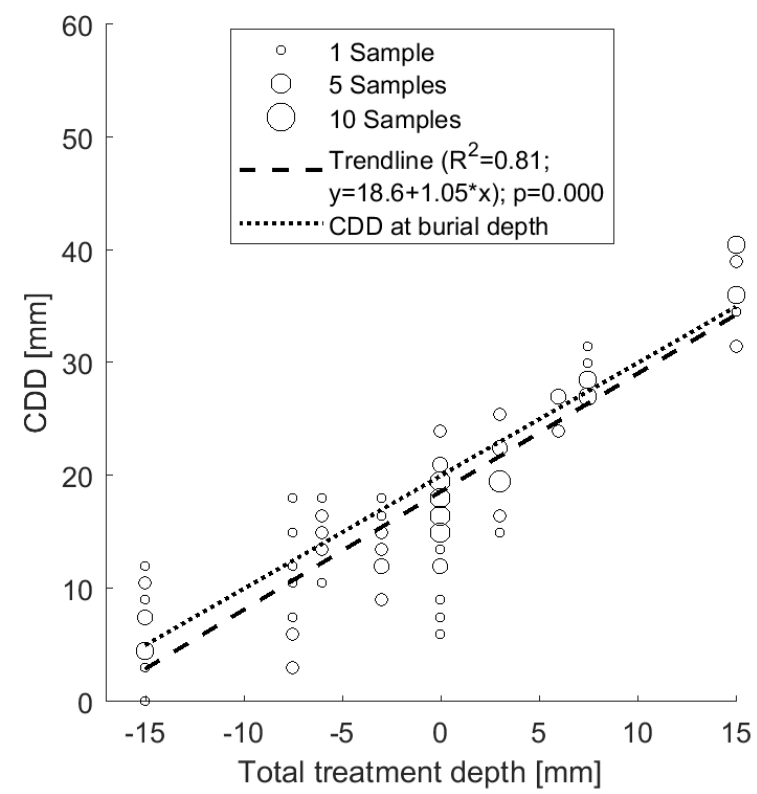

(a)

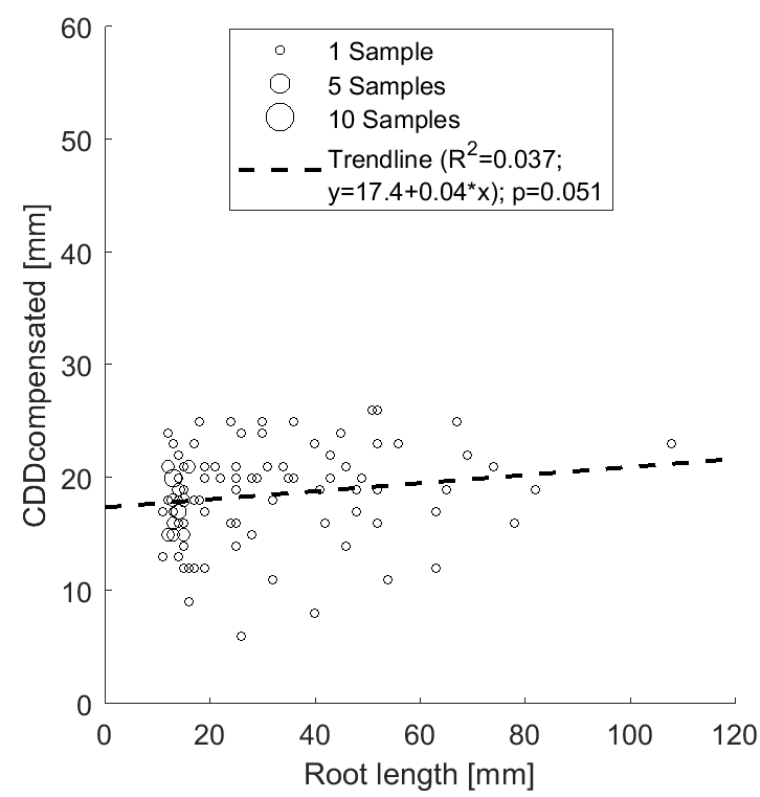

(c)

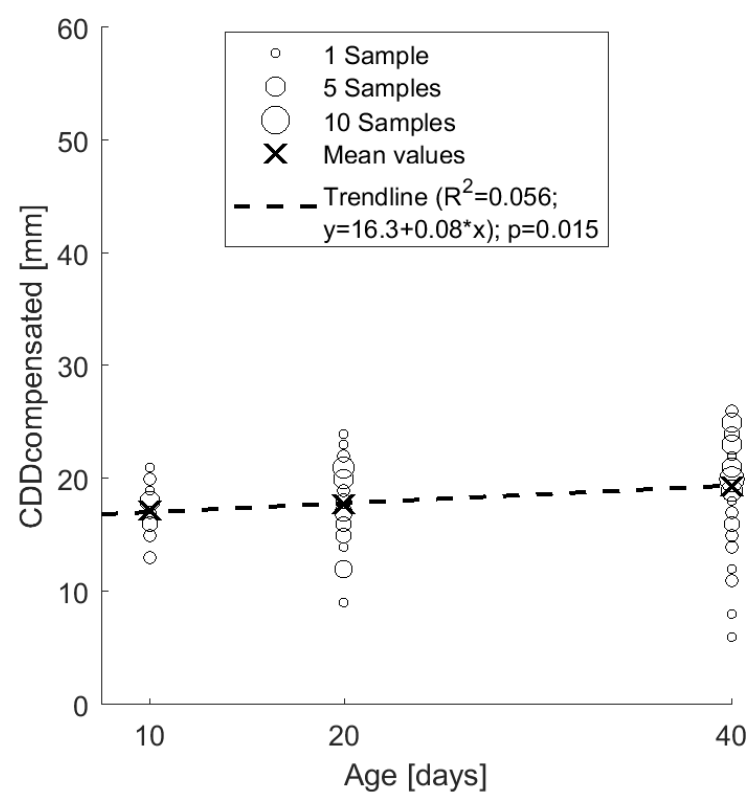

(b)

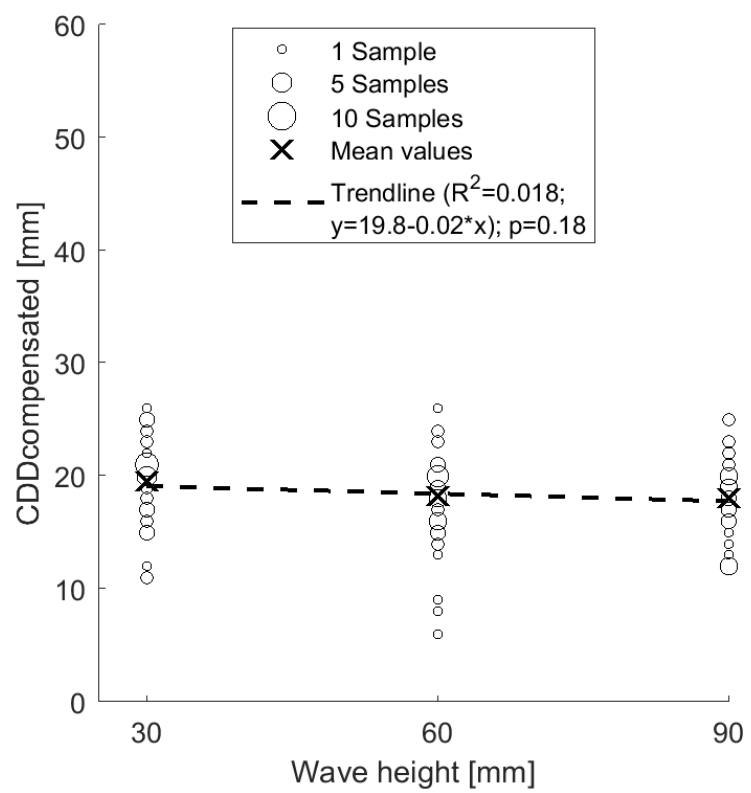

(d)

Figure 5: Plot of the effect of (a) accretion and erosion treatments, (b) seedling age, (c) root length and (d) wave height on $C D D$ and $C D D_{\text {compensated. }} C D D_{\text {compensated }}$ is the remaining variation in $C D D$ after removing the linear trend that is caused by treatments. The circle size of samples indicates the number of samples at a data point, ranging from 1 to 10 samples. $R^{2}$ indicates the Pearson correlation coefficient, $p$ the probability that no linear correlation exists between the two plotted variables. 


\subsection{WoO framework}

To predict the critical disturbance depth in the WoO framework, the combined effect of treatment depth and seedling age should be determined. Therefore, the values of the parameters in eq. 5 are determined using a multivariate linear regression analysis. This results in values of $16 \mathrm{~mm} ; 1.05$ and $0.09 \mathrm{~mm} /$ day for $\alpha_{1}, \alpha_{2}$ and $\alpha_{3}$ respectively. The values of $\alpha_{1}$ and $\alpha_{2}$ are used directly in the $\mathrm{WoO}$ framework for the initial CDD and the sensitivity to bed level change (see eq. 3 and eq. 4). The growth rate of $0.09 \mathrm{~mm}$ per day is multiplied by the duration of window 2 ( 80 days), resulting in a critical disturbance depth of $23 \mathrm{~mm}$ for mature plants.

$$
C D D=\alpha_{1}+\alpha_{2} * \text { treatment depth }+\alpha_{3} * \text { seedling age }
$$

\subsection{Morphodynamic model}

The morphodynamic model of the Marconi project without the use of wave-breaking measures predicted erosion (Figure 6). In the spin-up period (of half a year), some limited accretion occurred directly at the coast, while the rest of the domain showed up to 25 centimetres of erosion. In the following year, the erosion continued. This erosion was strongest near the coast and decreased in seaward direction, leading to a cliff between $+0.85 \mathrm{~m}$ and $+1.6 \mathrm{~m}$ (mean high water). The erosion was strong at the higher elevations near the coast, because the water depth in this area was by definition very low. Consequently, waves caused a relatively high bed shear stress and thereby erosion. In addition, the highest elevations were only inundated at high tide, when the cross-shore current and current-induced bed shear stress were at their maximum. At lower elevations further seaward, which also experience higher water depths, these effects were less pronounced.

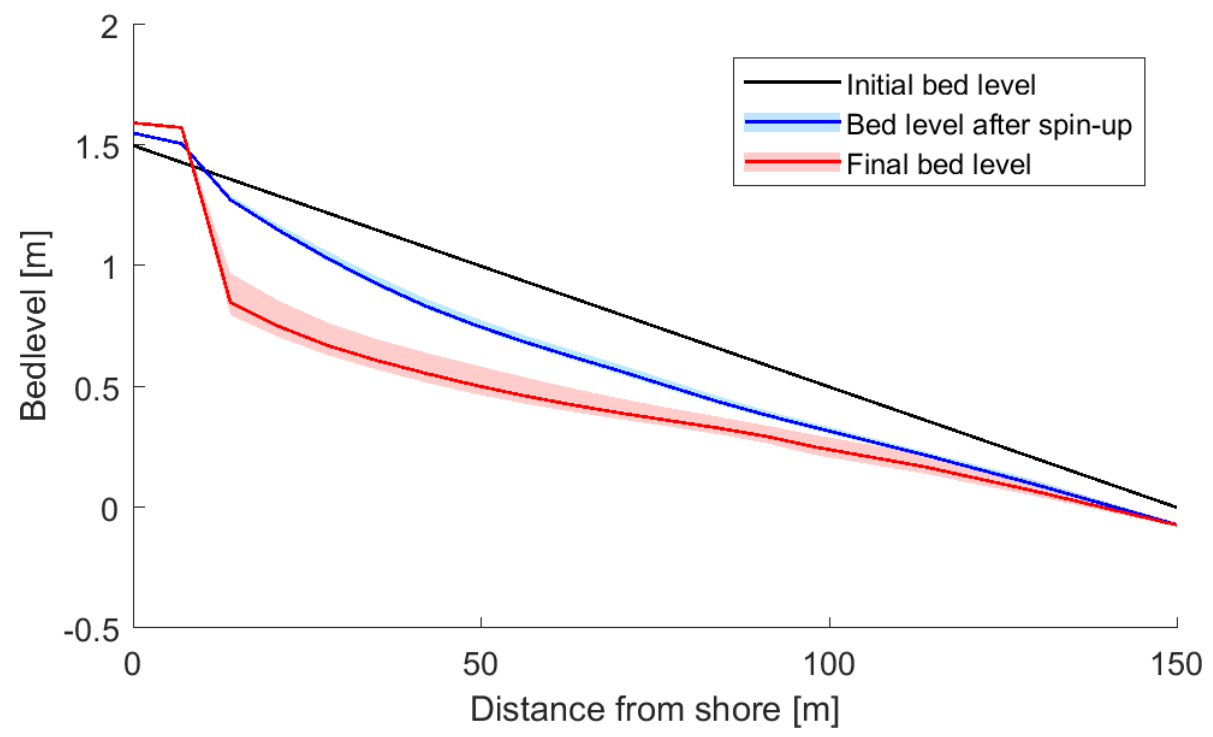

Figure 6: The cross-shore bed level profiles in the area of interest. The solid lines indicate the bed level in the centre, and the lighter areas the alongshore variation, i.e. the range from the minimum to the maximum bed level

Within the redefined WoO framework, the bed level is the central factor predicting vegetation establishment: window 1 depends on the bed level via the inundation duration, while window 2 and 3 depend directly on the bed level change. Figure 7 shows the effect of bed level development on vegetation establishment and the dependency on the wave height. At reference wave heights, establishment was only possible directly at the coast. This had a number of reasons (see Figure 8). Seaward of the cliff the bed became lower than high water at neap tide. Consequently, the innundationless period became shorter than 12 hours, so too short for window 1 to occur. Additionally, 
the limits for the average long-term erosion and short-term event erosion were exceeded in both window 2 and 3 due to the continuing erosion.

There is a slight difference between the location where window 1 was impossible and the location where window 2 and 3 became impossible (i.e. the area between the dotted red lines near the coast in Figure 8a). At the start of the establishment period, the elevation in this area was still above the high water level at neap tide. Consequently, a long enough dry period to fulfill window 1 did still exist. However, the continuing erosion prohibited window 2 and 3 from being successful. This means that establishment was not possible.

Further seaward the opposite occurred: window 1 was impossible, while window 2 and eventually 3 were possible (see the area between 50 and 150 metres from the coast in Figure 8a). As the erosion decreased in seaward direction, a point was reached where window 2 and 3 became possible again. However, the elevation was too low for the necessary dry period to occur. So establishment remained impossible.

Overall, window 3 failed at more locations than window 2. This has a number of reasons. Firstly, window 2 (80 days) is shorter than window 3 (at least half a year). Furthermore, window 3 takes place in the winter period, with more stormy hydrodynamic conditions and therefore more erosion. In addition, the critical disturbance depth depends in part on the previous bed level change (see the factor $\alpha \cdot \delta z_{\text {life }}$ in eq. 3 and 4 ). Erosion occurring during window 2 and 3 decreased the CDD, thereby contributing to the eventual failure of window 3 .

Reducing the wave height decreased the amount of erosion (Figure 7). For a 25 percent reduction in wave height, this had no effect on the establishment. Right at the coast, where the elevation was high enough for window 1 to succeed, the erosion was still too large for window 2 and 3 (Figure 7 and Figure $8 b)$. However, when the wave height was reduced by 50 percent, establishment did become more successful. With these waves, the establishment succeeded two rows of cells, or 15 metres, further from the coast (Figure 7 and Figure 8c).

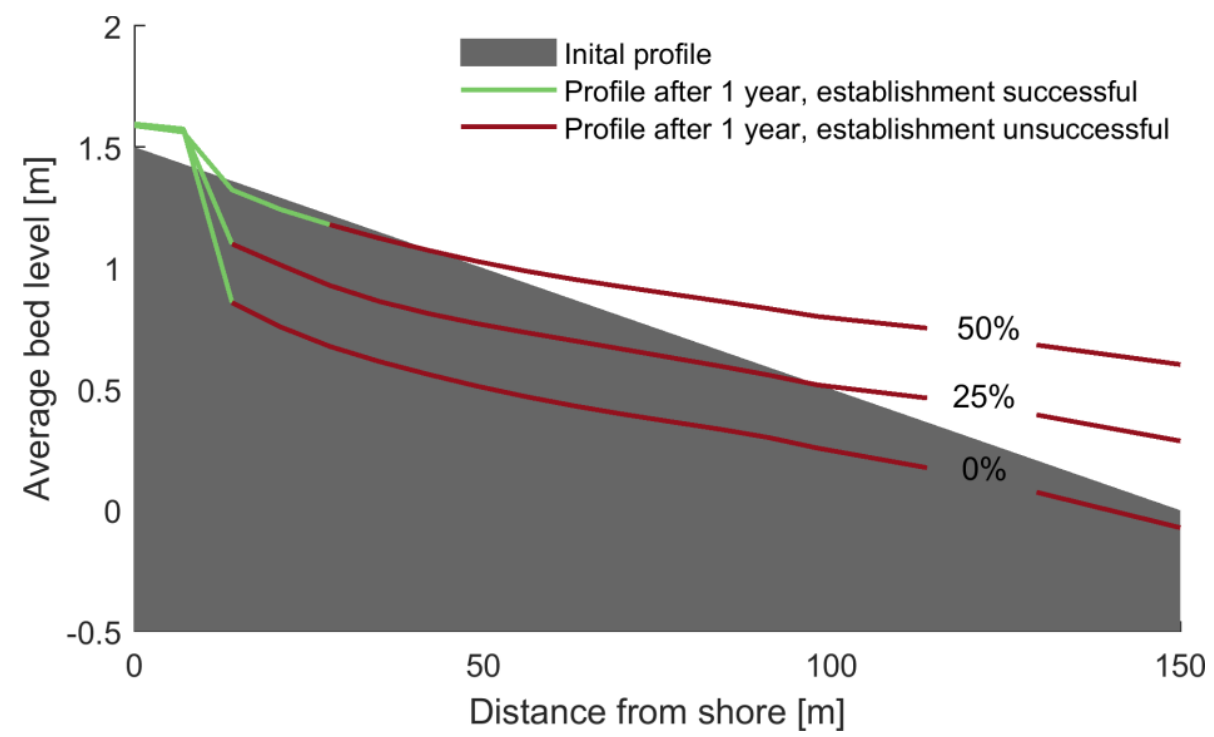

$440 \quad$ Figure 7: The effect of wave height on bed level development and establishment success. The lines indicate the profile of the bed in the centre of the area of interest with 0,25 and 50 percent of wave reduction. The colours indicate per position if the complete WoO framework has been finished successfully, and thereby if establishment could be successful. 


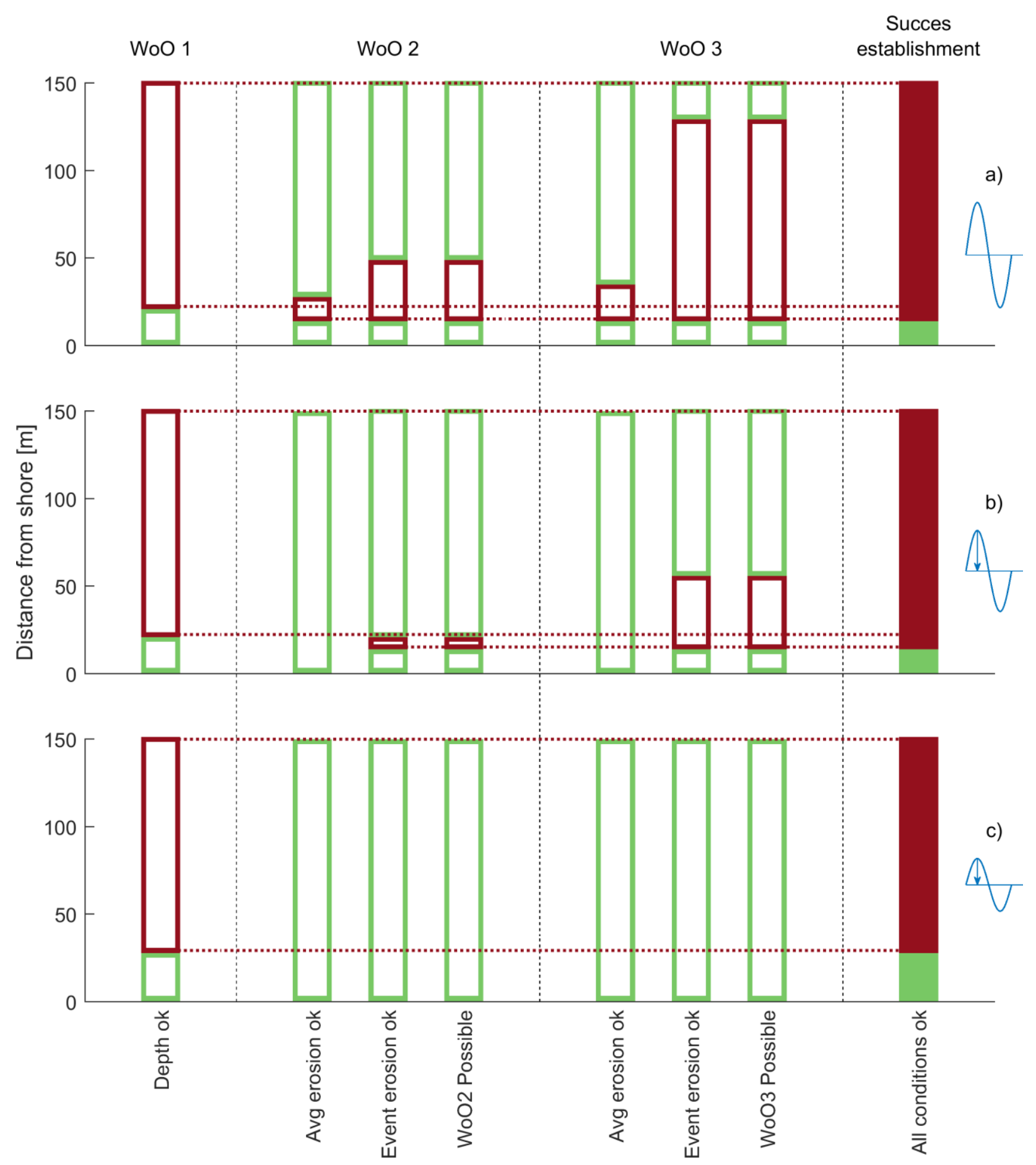

Figure 8: The success of vegetation establishment according to the WoO framework, for the profiles shown in figure 7. The success is plotted along the centre profile of the area of interest. Green indicates success, red indicates failure, framed bars indicate if a single criterion is met and the solid bars indicate the overall outcome, taking all criteria into account. Panel $a, b$, and $c$ show the outcome for respectively the reference wave height, a wave height reduction of 25 percent and a reduction of 50 percent. The criteria of window 2 and 3 that the average sedimentation should not be too high are met in every cell and for every wave height. Because of their irrelevance here, these criteria are not included in the figure. 


\section{Discussion}

\subsection{Flume experiment}

In this study, a flume experiment was used to determine the effect of seedling age, bed level change during seedling growth and wave height on the critical disturbance depth of Spartina seedlings. Bouma et al. (2016) and Cao et al. (2018) already showed that plants are very sensitive to bed level change. Our study adds a direct comparison of the effects of bed level change during seedling growth and wave height on the critical disturbance depth of seedlings. Bed level change was found to have a far larger effect than wave height. However, in the experiment the wave height was completely separated from the erosion, while in the field higher waves cause more erosion. Therefore, the result should not be interpreted to mean that wave heights do not matter. Rather, it means that the degree to which the action of wave induced drag on the vegetation affects seedling survival is largely controlled by the depth to which erosion has taken place in the immediate vicinity of the plant stem. As higher waves also cause more erosion, their effect can still be accounted for. Repeated bending of vegetation by high energy waves can also directly damage vegetation (Rupprecht et al., 2017; Vuik et al., 2018a). This can be seen as the high-energy equivalent of the toppling over of seedlings that is used in the CDD as failure criterion.

A difference with previous experiments is that we determined the CDD in a wave flume, while previous experiments only applied unidirectional currents. This set-up was based on the findings of Callaghan et al. (2010) that waves are dominant in salt marshes. The amount of erosion that seedlings in our study could withstand was 5 to $10 \mathrm{~mm}$ less than in the experiments of Bouma et al. (2016) and approximately $5 \mathrm{~mm}$ less than what Cao et al. (2018) found. Possibly plants topple more quickly under the alternating forces caused by waves, than under unidirectional forces and currents. Furthermore, the plants of our experiment did not grow equally well compared to the previous experiments, which might be caused by the growth conditions (i.e. the movement to a greenhouse in January and the slightly older seeds).

In the field, growth conditions like inundation time, salinity, nutrient availability and weather could cause additional variation in plant growth (Crooks et al., 2002; Friess et al., 2012; Smith \& Warren, 2012) and therefore CDD. Another potential difference is that the experimental accretion treatments were applied weekly, while in the field bed level change can range from almost continuously to concentrated in short periods of time (e.g. around spring time). Results from Cao et al. (2018) indicate that for a similar total magnitude, more continuous (more intermittent) bed level changes can decrease (increase) seedling mortality and lead to slightly higher (lower) CDD values.

\subsection{WoO framework}

In previous versions of the $\mathrm{WoO}$ framework (Attema, 2014; Hu et al., 2015b), the limits of window 2 and - if present - window 3 were defined in terms of bed shear stress. However, as Hu et al. (2015b) already indicated, this definition does not take into account the duration of the bed shear stress and the erosion this causes. Therefore, we defined the limits directly in terms of bed level change (erosion and sedimentation). The experiment supports this definition: plants were much more sensitive to erosion than to wave height and bed shear stress. An added benefit of this approach is that it allows taking into account the effect of previous erosion and sedimentation on plant growth. Furthermore, erosion is easier to determine in the field, making it practically more convenient to use. Determining the bed shear stress requires detailed flow velocity measurements or hydrodynamic modelling (Pope et al., 2006; Hu et al., 2015b) and is further complicated when waves and currents occur simultaneously (see e.g. Soulsby \& Clarke, 2005). Erosion in contrast can be measured directly in the field (Haigh, 1977). Given the temporally highly varied nature of bed level change in the pioneer zone near the seaward salt marsh 
edge (Best et al., 2018) and the role of erosion in our revised WoO framework, these bed level measurements should be high-frequency, long-term and continuous. Recent advances have made the collection of such measurements possible (Hu et al., 2015a).

The variability in the flume experiment and the differences with earlier experiments highlight the inherent variability of ecological processes. Hence, the resulting framework should not be seen as a quantitative prediction of the exact establishment location and necessary magnitude of wave dampening measures. Rather, it should be used to obtain a mechanistic insight into the hydrodynamic conditions limiting salt marsh establishment and the possible measures to target these conditions.

\subsection{Morphodynamic model}

505 As a case study, we examined how the WoO framework can be used in practice. By combining the WoO framework with a Delft3D model, the hydrodynamics, morphological development and vegetation establishment at the Marconi pioneer salt marsh were predicted. For the establishment and long-term stability of this salt marsh, the bed level should ideally be in equilibrium or accrete. In the Delft3D model this was not the case.

510 As explained in the results, the erosion in Delft3D is caused by the high bed shear stress near the coast. The area of Marconi currently consists of intertidal mudflats. If the bed level is raised (as is planned to facilitate the growth of a salt marsh), the morphological equilibrium is disturbed. The Delft3D model does not contain any measures against erosion (e.g. wave dampening). Therefore, it makes sense that the system tries to return to its old equilibrium, and continues doing so after the morphological spin-up 515 period.

The sediment in the model is a uniformly defined homogeneous cohesive sediment, with constant concentrations at the boundaries. In the field, the sediment type and sediment concentration would vary by place and time. As shown by for instance Van der Wegen and Jaffe (2013) and Dalledonne (2017), the sediment properties strongly affect the morphological response of a model. This means that the 520 definition of the sediment type and boundary conditions form a source of uncertainty in the Delft3D model.

The Delft3D model was set up in order to predict vegetation establishment. The impact of this vegetation on the hydrodynamics was not explicitly accounted for in the model. This is acceptable because this study only aims to model vegetation establishment and not long-term morphological development (like e.g. Schwarz et al., 2014). Young seedlings have a small density and height and vegetation is only found to grow in a narrow band of approximately $15 \mathrm{~m}$ along the coast, limiting the effect on the hydrodynamics.

At higher densities, plants would attenuate waves and decrease erosion. In flume experiments by Bouma et al. (2009), a density of approximately 1500 established shoots $/ \mathrm{m}^{2}$ was needed before enhanced 530 sediment accretion occurred within Spartina anglica tussocks. However, this threshold density depends on local conditions. Given the decrease in erosion at high seedling densities, an approach without vegetation-wave interaction would underestimate the establishment success at high seedling densities. Apart from the saltmarsh vegetation itself, other biostabilizing biota such as diatoms and algae can stabilize the bed, while bioturbators such as clams and snails (e.g. Macoma balthica and Hydrobia ulvae) can destabilize the bed (Paterson, 1989; Widdows \& Brinsley, 2002).

Differences in the sediment characteristics, boundary concentrations and possible effects from saltmarsh plants and other biota cause uncertainty in the model and can ultimately cause inaccurate predictions of the degree of erosion. This makes it critical to validate the model in the future. A more 
thorough assessment of uncertainty in biophysical model input would be to apply a probabilistic approach (see Vuik et al., 2018b). In the absence of validation, the Delft3D model still serves well as illustration of the possibilities of the WoO framework. However, for Marconi the predicted bed level change should be regarded more as directional prediction (i.e. in the absence of wave breaking measures, strong erosion will occur) than as exact value.

The predicted vegetation establishment follows the morphological results, with a bimodal distribution 545 of establishment chances. Directly at the coast, disturbance-free periods are abundant and erosion is virtually absent. Consequently, all windows can be completed successfully, resulting in vegetation establishment. Below the cliff, the elevation is too low for sufficiently long disturbance-free periods to occur. Consequently, window 1 is unsuccessful (apart from the cells directly below the cliff, where the elevation at the start of the growing season is still sufficient for window 1). Furthermore, the strong erosion seaward of the cliff prohibits the success of window 2 and 3.

The predicted establishment pattern is quite robust, because several criteria are simultaneously limiting establishment seaward of the cliff. Varying the parameter values in the $\mathrm{WoO}$ framework indicated that the model outcome does not depend on individual parameter values: establishment remains only possible (at the two rows of cells) near the coast. Regarding the possible success of the separate windows, the duration of window $2\left(\mathrm{~T}_{\mathrm{WoO} 2}\right)$ and the critical disturbance depth of mature vegetation $\left(\mathrm{CDD}_{\text {mature }}\right)$ have most effect. The imminent execution of the Marconi experiment and the monitoring data that will be collected will help to clarify the quality of the predictions and narrow down the uncertainty in the parameter values used.

The effect of wave dampening on vegetation establishment was also examined. Wave dampening decreased the amount of erosion and increased sedimentation. Consequently, establishment could succeed slightly further seaward (15 metres, in the model). Past this point, the elevation was still too low for window 1 to succeed. For Marconi, this showed that in the absence of engineering measures multiple conditions (i.e. the low elevation and strong bed level change) are simultaneously limiting vegetation establishment. In a subsequent design phase, the use of specific engineering measures instead of the previously examined lowering of the boundary wave height by undefined means - could be examined by implementing them in the model. Examples of these measures are hard structures to create a sheltered zone; brushwood sediment fences to dissipate wave energy or actively planting vegetation (i.e. ignoring window 1 ).

\subsection{General applicability}

570 Future users of the framework should note that the WoO framework has only been tested at shallow water depths and low waves (13 to $30 \mathrm{~cm}$ water depth, 3 to $9 \mathrm{~cm}$ wave height). For Marconi, the average modelled wave height in cells with establishment was $6 \mathrm{~cm}$, with final water depths up to $85 \mathrm{~cm}$ at spring tide. So the wave heights agreed quite well with the values used in the flume experiment, but the maximum water depths were somewhat higher. In addition, users should remember that it is crucial to use reliable time series for the bed level change, as these directly determine the predicted establishment success. If morphodynamic modelling is used to obtain the time series, users should take care in the definition of the sediment characteristics and boundary conditions, take into account the effect that (other) biota can have on the substrate and hydrodynamics, and where possible validate their model.

In general, this paper has shown that the Windows of Opportunity framework is a valuable tool, which 580 can be used by coastal managers looking to implement ecological engineering solutions at a certain location. Given the uncertainties inherent to the approach, stemming from uncertainties in WoO parameters, the intrinsic variability of seedlings and the modelling of bed level change, users should 
focus on obtaining mechanistic insights (e.g. if a salt marsh can establish and whether salt marsh establishment is limited by waves in general, high waves during storms or along-shore currents). These insights can subsequently be used to design measures that create favourable conditions for salt marsh establishment.

\section{Conclusions}

In this study we examined for the first time how bed level change can be used directly to predict salt marsh establishment. The flume experiment showed that Spartina seedlings are very sensitive to bed level change over time. Therefore, we revised the Windows of Opportunity framework, using bed level change as the driving mechanism. The framework now reflects the physical process of salt marsh establishment better, because it takes into account A) the dependency of seedling strength on past bed level change that occurred during seedling growth and B) the effect of frequent but less extreme events that cause significant bed level change over time. Key sources of uncertainty in the WoO framework are the effect of various growth conditions and seedling behaviour during stronger hydrodynamic conditions. These factors should be addressed in future experiments, as well the parameter values for other salt marsh species. Combining this framework with a Delft3D model of the Marconi salt marsh revealed that at the Marconi project bed level change needs to be decreased by wave dampening measures, to create the sheltered conditions necessary for salt marsh establishment. In a broader sense, this case study demonstrated the value of the Windows of Opportunity framework as a tool to predict salt marsh establishment on tidal flats. With it, coastal managers can determine whether salt marsh establishment is possible and which conditions are limiting the establishment. Furthermore, it can help to determine the functional specifications of engineering measures that are required to create the conditions necessary for salt marsh establishment.

\section{Acknowledgements}

This work is part of the research programme BE SAFE, which is financed by the Netherlands Organisation for Scientific Research (NWO) (850.13.010). Additional financial support has been provided by NIOZ, Ecoshape, Deltares, Boskalis, Van Oord, Rijkswaterstaat, World Wildlife Fund and HZ University of Applied Science. Moreover, we acknowledge Yifei Gu, Bert Sinke and Lennart van

610 IJzerloo for assisting in the flume experiments at NIOZ Yerseke. Next, Ecoshape is acknowledged for providing the pilot project Marconi as case study in this paper. Finally, Bas Borsje is supported by the Netherlands Organization for Scientific Research (NWO-STW-VENI; 4363).

\section{References}

Attema, Y. (2014). Long-term bio-geomorphological modelling of the formation and succesion of salt marshes. (MSc. thesis), Delft University of Technology, Delft.

Balke, T., Bouma, T. J., Horstman, E. M., Webb, E. L., Erftemeijer, P. L. A., \& Herman, P. M. J. (2011). Windows of opportunity: thresholds to mangrove seedling establishment on tidal flats. Marine Ecology Progress Series, 440, 1-9. doi:10.3354/meps09364

Balke, T., Herman, P. M. J., \& Bouma, T. J. (2014). Critical transitions in disturbance-driven ecosystems: identifying Windows of Opportunity for recovery. Journal of Ecology, 102(3), 700708. doi:10.1111/1365-2745.12241

Beck, M. W., Heck Jr, K. L., Able, K. W., Childers, D. L., Eggleston, D. B., Gillanders, B. M., . . . Minello, T. J. (2001). The identification, conservation, and management of estuarine and marine nurseries for fish and invertebrates: a better understanding of the habitats that serve as nurseries for marine species and the factors that create site-specific variability in nursery quality will improve conservation and management of these areas. Bioscience, 51(8), 633-641. doi:10.1641/0006-3568(2001)051[0633:TICAMO]2.0.CO;2 
Best, Ü. S. N., Van der Wegen, M., Dijkstra, J., Willemsen, P. W. J. M., Borsje, B. W., \& Roelvink, D. J. A. (2018). Do salt marshes survive sea level rise? Modelling wave action, morphodynamics and vegetation dynamics. Environmental Modelling \& Software, 109, 152-166. doi:10.1016/j.envsoft.2018.08.004

Bockelmann, A. C., Bakker, J. P., Neuhaus, R., \& Lage, J. (2002). The relation between vegetation zonation, elevation and inundation frequency in a Wadden Sea salt marsh. Aquatic Botany, 73(3), 211-221. doi:10.1016/S0304-3770(02)00022-0

635 Booij, N., Ris, R. C., \& Holthuijsen, L. H. (1999). A third-generation wave model for coastal regions: 1. Model description and validation. Journal of Geophysical Research: Oceans, 104(C4), 76497666. doi:10.1029/98JC02622

Borsje, B., W., Van Wesenbeeck, B. K., Dekker, F., Paalvast, P., Bouma, T. J., Van Katwijk, M. M., \& De Vries, M. B. (2011). How ecological engineering can serve in coastal protection. Ecological Engineering, 37(2), 113-122. doi:10.1016/j.ecoleng.2010.11.027

Borsje, B. W., De Vries, M. B., Hulscher, S. J. M. H., \& De Boer, G. J. (2008). Modeling large-scale cohesive sediment transport affected by small-scale biological activity. Estuarine, Coastal and Shelf Science, 78(3), 468-480. doi:10.1016/j.ecss.2008.01.009

Bouma, T. J., Friedrichs, M., Van Wesenbeeck, B., Temmerman, S., Graf, G., \& Herman, P. (2009). Density-dependent linkage of scale-dependent feedbacks: A flume study on the intertidal macrophyte Spartina anglica. Oikos, 118(2), 260-268. doi:10.1111/j.1600-0706.2008.16892.x

Bouma, T. J., Van Belzen, J., Balke, T., Van Dalen, J., Klaassen, P., Hartog, A. M., . . Herman, P. M. J. (2016). Short-term mudflat dynamics drive long-term cyclic salt marsh dynamics. Limnology and Oceanography, 2161-2175. doi:10.1002/lno.10374

650 Brevik, E. C., \& Homburg, J. A. (2004). A 5000 year record of carbon sequestration from a coastal lagoon and wetland complex, Southern California, USA. CATENA, 57(3), 221-232. doi:10.1016/j.catena.2003.12.001

Broekx, S., Smets, S., Liekens, I., Bulckaen, D., \& De Nocker, L. (2011). Designing a long-term flood risk management plan for the Scheldt estuary using a risk-based approach. Natural hazards, 57(2), 245-266. doi:10.1007/s11069-010-9610-x

Callaghan, D. P., Bouma, T. J., Klaassen, P., van der Wal, D., Stive, M. J. F., \& Herman, P. M. J. (2010). Hydrodynamic forcing on salt-marsh development: Distinguishing the relative importance of waves and tidal flows. Estuarine, Coastal and Shelf Science, 89(1), 73-88. doi:10.1016/j.ecss.2010.05.013

660 Cao, H., Zhu, Z., Balke, T., Zhang, L., \& Bouma, T. J. (2018). Effects of sediment disturbance regimes on Spartina seedling establishment: implications for salt marsh creation and restoration. Limnology and Oceanography, 63(2), 647-659. doi:10.1002/lno.10657

Chmura, G. L. (2013). What do we need to assess the sustainability of the tidal salt marsh carbon sink? Ocean and Coastal Management, 83, 25-31. doi:10.1016/j.ocecoaman.2011.09.006

Corenblit, D., Baas, A. C. W., Bornette, G., Darrozes, J., Delmotte, S., Francis, R. A., . . Steiger, J. (2011). Feedbacks between geomorphology and biota controlling Earth surface processes and landforms: A review of foundation concepts and current understandings. Earth-Science Reviews, 106(3-4), 307-331. doi:10.1016/j.earscirev.2011.03.002

Crooks, S., Schutten, J., Sheern, G. D., Pye, K., \& Davy, A. J. (2002). Drainage and elevation as factors 670 in the restoration of salt marsh in Britain. Restoration Ecology, 10(3), 591-602. doi:10.1046/j.1526-100X.2002.t01-1-02036.x

Dalledonne, G. (2017). Analysis and assessment of uncertainties in coastal morphodynamic modelling. Universitätsbibliothek Kiel. 
Dankers, P., Verhoogt, H., Van Nieuwerburgh, L., Akkerman, G. J., Peerbolte, B., Schaafsma, M., .. . Smit, C. (2013). Ecodynamische variantenanalyse kustontwikkeling Delfzijl: Onderzoek naar mogelijkheden van strand- en kwelderaanleg en dijkversterking. Retrieved from Nijmegen:

De Groot, A. V., \& Van Duin, W. E. (2013). Best practices for creating new salt marshes in a saline estuarine setting, a literature study (Imares C145/12). Retrieved from

Deltares. (2016). Delft3D-Flow: Simulation of multi-dimensional hydrodynamic flows and transport phenomena, including sediments (User Manual). Retrieved from Delft:

Duarte, C. M., Losada, I. J., Hendriks, I. E., Mazarrasa, I., \& Marba, N. (2013). The role of coastal plant communities for climate change mitigation and adaptation. Nature Clim. Change, 3(11), 961-968. doi:10.1038/nclimate1970

685

Fagherazzi, S. (2014). Coastal processes: Storm-proofing with marshes. Nature Geoscience, 7(10), 701. doi:10.1038/ngeo2262

Friess, D. A., Krauss, K. W., Horstman, E. M., Balke, T., Bouma, T. J., Galli, D., \& Webb, E. L. (2012). Are all intertidal wetlands naturally created equal? Bottlenecks, thresholds and knowledge gaps to mangrove and saltmarsh ecosystems. Biological Reviews, 87(2), 346-366. doi:10.1111/j.1469185X.2011.00198.X

Haigh, M. (1977). The Use of Erosion Pins in the Study of Slope Evolution Technical Bulletin No. 18, Shorter Technical Methods (II): Britisch Geomorphological Research Group.

Horstman, E. M., Dohmen-Janssen, C. M., Bouma, T. J., \& Hulscher, S. J. M. H. (2015). Tidal-scale flow routing and sedimentation in mangrove forests: Combining field data and numerical modelling. Geomorphology, 228, 244-262. doi:10.1016/j.geomorph.2014.08.011

Hu, Z., Lenting, W., Van der Wal, D., \& Bouma, T. J. (2015a). Continuous monitoring bed-level dynamics on an intertidal flat: Introducing novel, stand-alone high-resolution SED-sensors. Geomorphology, 245, 223-230. doi:10.1016/j.geomorph.2015.05.027

Hu, Z., Van Belzen, J., Van der Wal, D., Balke, T., Wang, Z. B., Stive, M. J. F., \& Bouma, T. J. (2015b). Windows of opportunity for salt marsh vegetation establishment on bare tidal flats: The importance of temporal and spatial variability in hydrodynamic forcing. Journal of Geophysical Research: Biogeosciences, 120(7), 1450-1469. doi:10.1002/2014JG002870

Janssen, S. K. H. (2015). Greening flood protection in the Netherlands : a knowledge arrangement approach. Wageningen University, Wageningen.

Kirwan, M. L., \& Megonigal, J. P. (2013). Tidal wetland stability in the face of human impacts and sealevel rise. Nature, 504(7478), 53-60. doi:10.1038/nature12856

Leonardi, N., Ganju, N. K., \& Fagherazzi, S. (2016). A linear relationship between wave power and erosion determines salt-marsh resilience to violent storms and hurricanes. Proceedings of the National Academy of Sciences, 113(1), 64-68. doi:10.1073/pnas.1510095112

Lesser, G. R., Roelvink, J. A., Van Kester, J. A. T. M., \& Stelling, G. S. (2004). Development and validation of a three-dimensional morphological model. Coastal engineering, 51(8), 883-915. doi:10.1016/j.coastaleng.2004.07.014

Marciano, R., Wang, Z. B., Hibma, A., De Vriend, H. J., \& Defina, A. (2005). Modeling of channel patterns in short tidal basins. Journal of Geophysical Research: Earth Surface, 110(F1), n/a-n/a. doi:10.1029/2003JF000092

715 Massel, S. R. (1996). On the largest wave height in water of constant depth. Ocean Engineering, 23(7), 553-573. doi:10.1016/0029-8018(95)00049-6

Möller, I., Kudella, M., Rupprecht, F., Spencer, T., Paul, M., Van Wesenbeeck, B. K., . . MirandaLange, M. (2014). Wave attenuation over coastal salt marshes under storm surge conditions. Nature Geoscience, 7(10), 727-731. doi:10.1038/ngeo2251 
Nelson, J. L., \& Zavaleta, E. S. (2012). Salt Marsh as a Coastal Filter for the Oceans: Changes in Function with Experimental Increases in Nitrogen Loading and Sea-Level Rise. PLOS ONE, 7(8), e38558. doi:10.1371/journal.pone.0038558

Partheniades, E. (1965). Erosion and deposition of cohesive soils. Journal of the Hydraulics Division, 91(1), 105-139.

Paterson, D. M. (1989). Short-term changes in the erodibility of intertidal cohesive sediments related to the migratory behavior of epipelic diatoms. Limnology and Oceanography, 34(1), 223-234.

Pethick, J. (2002). Estuarine and Tidal Wetland Restoration in the United Kingdom: Policy Versus Practice. Restoration Ecology, 10(3), 431-437. doi:10.1046/j.1526-100X.2002.01033.x

Pope, N. D., Widdows, J., \& Brinsley, M. D. (2006). Estimation of bed shear stress using the turbulent kinetic energy approach-A comparison of annular flume and field data. Continental Shelf Research, 26(8), 959-970. doi:10.1016/j.csr.2006.02.010

Powell, E. J., Tyrrell, M. C., Milliken, A., Tirpak, J. M., \& Staudinger, M. D. (2017). A synthesis of thresholds for focal species along the U.S. Atlantic and Gulf Coasts: A review of research and applications. Ocean \& Coastal Management, 148, 75-88. doi:10.1016/j.ocecoaman.2017.07.012

Rijkswaterstaat. (2013). Kenmerkende waarden getijdegebied. Retrieved from https://staticresources.rijkswaterstaat.nl/binaries/Kenmerkende\%20waarden\%20getijgebied\%202 011_tcm21-97249.pdf

Roman, C. T., \& Burdick, D. M. (2012). Tidal marsh restoration: a synthesis of science and management: Island Press.

740 Rupprecht, F., Möller, I., Paul, M., Kudella, M., Spencer, T., Van Wesenbeeck, B., . . Miranda-Lange, M. (2017). Vegetation-wave interactions in salt marshes under storm surge conditions. Ecological Engineering, 100, 301-315. doi:10.1016/j.ecoleng.2016.12.030

Schwarz, C., Ye, Q. H., Van der Wal, D., Zhang, L. Q., Bouma, T., Ysebaert, T., \& Herman, P. M. J. (2014). Impacts of salt marsh plants on tidal channel initiation and inheritance. Journal of Geophysical Research: Earth Surface, 119(2), 385-400. doi:10.1002/2013JF002900

Smith, S. M., \& Warren, R. S. (2012). Vegetation Responses to Tidal Restoration. In C. T. Roman \& D. M. Burdick (Eds.), Tidal Marsh Restoration: A Synthesis of Science and Management. Washington: Island Press.

Soulsby, R. L., \& Clarke, S. (2005). Bed Shear-stresses Under Combined Waves and Currents on Smooth and Rough Beds. Retrieved from Wallingford, UK:

Spalding, M. D., Ruffo, S., Lacambra, C., Meliane, I., Hale, L. Z., Shepard, C. C., \& Beck, M. W. (2014). The role of ecosystems in coastal protection: Adapting to climate change and coastal hazards. Ocean \& Coastal Management, 90, 50-57. doi:10.1016/j.ocecoaman.2013.09.007

Taal, M. D., Schmidt, C. A., Brinkman, A. G., Stolte, W., \& Van Maren, D. S. (2015). Slib en primaire productie in het Eems-estuarium: Een samenvatting van vier jaar meten, modelleren, kennis bundelen en verwerven. Retrieved from Delft:

Temmerman, S., Bouma, T. J., Govers, G., \& Lauwaet, D. (2005). Flow paths of water and sediment in a tidal marsh: Relations with marsh developmental stage and tidal inundation height. Estuaries, 28(3), 338-352. doi:10.1007/bf02693917

Temmerman, S., Meire, P., Bouma, T. J., Herman, P. M. J., Ysebaert, T., \& De Vriend, H. J. (2013). Ecosystem-based coastal defence in the face of global change. Nature, 504(7478), 79. doi:10.1038/nature12859

Turner, R. K., Burgess, D., Hadley, D., Coombes, E., \& Jackson, N. (2007). A cost-benefit appraisal of coastal managed realignment policy. Global Environmental Change, 17(3), 397-407. doi:10.1016/j.gloenvcha.2007.05.006

Van der Wegen, M., \& Jaffe, B. E. (2013). Towards a probabilistic assessment of process-based, morphodynamic models. Coastal engineering, 75, 52-63. doi:10.1016/j.coastaleng.2013.01.009 
Van Leeuwen, B., Augustijn, D. C. M., Van Wesenbeeck, B. K., Hulscher, S. J. M. H., \& De Vries, M. B. (2010). Modeling the influence of a young mussel bed on fine sediment dynamics on an intertidal flat in the Wadden Sea. Ecological Engineering, 36(2), 145-153. doi:10.1016/j.ecoleng.2009.01.002

Van Maren, D. S., Van Kessel, T., Cronin, K., \& Sittoni, L. (2015a). The impact of channel deepening and dredging on estuarine sediment concentration. Continental Shelf Research, 95, 1-14. doi:10.1016/j.csr.2014.12.010

Van Maren, D. S., Vroom, J., Vijverberg, T., Schoemans, M., \& Van Rooijen, A. (2014). Mud dynamics in the Ems-Dollard, phase 2 - Setup hydrodynamic models. Retrieved from Delft:

Van Maren, D. S., Winterwerp, J. C., \& Vroom, J. (2015b). Fine sediment transport into the hyperturbid lower Ems River: the role of channel deepening and sediment-induced drag reduction. Ocean Dynamics, 65(4), 589-605.

Van Rijn, L. C. (1993). Principles of sediment transport in rivers, estuaries and coastal seas (Vol. 1006): Aqua publications Amsterdam.

Van Slobbe, E., De Vriend, H. J., Aarninkhof, S., Lulofs, K., De Vries, M. B., \& Dircke, P. (2013). Building with Nature: In search of resilient storm surge protection strategies. Natural hazards, 65(1), 947-966. doi:10.1007/s11069-012-0342-y

Vernberg, F. J. (1993). Salt-marsh processes: a review. Environmental Toxicology and Chemistry, 12, 2167-2195.

Vuik, V., Jonkman, S. N., Borsje, B. W., \& Suzuki, T. (2016). Nature-based flood protection: The efficiency of vegetated foreshores for reducing wave loads on coastal dikes. Coastal engineering, 116, 42-56. doi:10.1016/j.coastaleng.2016.06.001

Vuik, V., Suh Heo, H. Y., Zhu, Z., Borsje, B. W., \& Jonkman, S. N. (2018a). Stem breakage of salt marsh vegetation under wave forcing: A field and model study. Estuarine, Coastal and Shelf Science, 200, 41-58. doi:10.1016/j.ecss.2017.09.028

Vuik, V., van Vuren, S., Borsje, B. W., van Wesenbeeck, B. K., \& Jonkman, S. N. (2018b). Assessing safety of nature-based flood defenses: Dealing with extremes and uncertainties. Coastal engineering, 139, 47-64. doi:10.1016/j.coastaleng.2018.05.002

Widdows, J., \& Brinsley, M. (2002). Impact of biotic and abiotic processes on sediment dynamics and the consequences to the structure and functioning of the intertidal zone. Journal of sea Research, 48(2), 143-156. doi:10.1016/S1385-1101(02)00148-X

Willemsen, P. W. J. M., Horstman, E. M., Borsje, B. W., Friess, D. A., \& Dohmen-Janssen, C. M. (2016). Sensitivity of the sediment trapping capacity of an estuarine mangrove forest. Geomorphology, 273, 189-201. doi:10.1016/j.geomorph.2016.07.038

Winterwerp, J. C., \& Van Kesteren, W. G. M. (2004). Introduction to the physics of cohesive sediment dynamics in the marine environment (Vol. 56). Amsterdam: Elsevier.

Wolters, M., Garbutt, A., \& Bakker, J. P. (2005). Salt-marsh restoration: evaluating the success of deembankments in north-west Europe. Biological Conservation, 123(2), 249-268. doi:10.1016/j.biocon.2004.11.013 